\title{
Is Epistemology Autonomous?
}

\author{
Penultimate Draft, forthcoming in Metaepistemology \\ Daniel Greco
}

\section{Introduction}

It's commonly — though by no means universally — held that the best metaethical account of our moral thought and language won't place any significant constraints on our first-order ethical theorizing; once we have the right metaethics, we can go on having the same first-order ethical debates, and accepting the same first-order ethical views. This thesis of the "autonomy of ethics" is particularly popular among writers in the expressivist tradition. A.J. Ayer wrote that "a strictly philosophical treatise on ethics should make no ethical pronouncements," (1971, p.106) and contemporary expressivists have tended to agree that their metaethical views do not limit their normative ethical options. ${ }^{1}$

Setting aside the question of whether this is right (though I'll return to it), I'll argue that broadly expressivist metanormative commitments have significant consequences in what look like first-order normative epistemological debates. Though ultimately, my discussion may be better understood as problematizing the distinction between firstorder epistemology, and metaepistemology. I'll start with the example of judgment internalism - a thesis endorsed by expressivists, but many non-expressivists as well.

\footnotetext{
For helpful comments and discussion, thanks to two anonymous referees for this volume, as well as Connor McHugh.

${ }^{1}$ See Schroeder (Forthcoming) for some helpful discussion of how various metaethical views do or don't carry normative ethical commitments, and in particular a neat summary of why traditional versions of non-cognitivism, like Ayer's, seem to carry few if any such commitments.
} 


\section{Is Epistemology Autonomous?}

While generally seen as irrelevant to first-order ethical debates, I'll argue that judgment internalism has significant consequences for some putatively "first-order" debates in epistemology. I'll go on to argue that accepting more thoroughly expressivist metaepistemological commitments has more far-reaching epistemological consequences, focusing on the internalism/externalism debate.

To see why autonomy theses can seem plausible to the expressivist, it may help to start with some metaethical views on which autonomy theses straightforwardly fail. Constructivist views are an instructive example. Constructivist views hold that the normative truths are somehow constructed by agents - they are somehow grounded in facts about what agents do or would want, or agree to, or endorse. As defended by contemporary metaethicists, constructivism tends to have significant, sometimes surprising first-order normative consequences. Take, for instance, the Humean variety of constructivism defended by Sharon Street (2009b). It entails that a sufficiently clear-headed, procedurally rational agent who wants nothing more than to inflict as much suffering as he can - an "ideally coherent Caligula", in the lingo- has no reason not to do so; when he tortures helpless peasants, he is doing what he has most reason to do. This is because what we have reason to do, according to Street, depends on what we would in fact be motivated to do after sufficiently careful deliberation. The Kantian version of constructivism defended by Korsgaard (2000), while perhaps less revisionary, is no less substantive in its entailments about what we ought to do.

Why are expressivist views supposed to avoid these sorts of commitments? Roughly, the answer is that the expressivist says nothing about what grounds normative truths. In this respect, she is like the so-called "quietist realists". ${ }^{2}$ Rather, she gives us a theory about what it is to believe that something is a normative truth. This will involve a distinctive sort of mental state, importantly unlike our beliefs concerning non-normative matters. Depending on the version of expressivism, it might involve having various

\footnotetext{
${ }^{2}$ See McPherson (2011) for a discussion of the category, in which he places Scanlon, Parfit, and others.
} 


\section{Is Epistemology Autonomous?}

sentiments ${ }^{3}$, or accepting various norms, ${ }^{4}$ or being committed to various plans. ${ }^{5}$ To take a toy example, suppose our expressivist holds that to believe that $\phi$-ing is wrong is to be disposed to feel guilty when one $\phi$ 's, and to feel angry at others when they $\phi$. Expressivists tend to hold that such emotions can, in principle, be directed towards just about any object. Pace Foot, they hold that we can imagine a society where children are scolded if they step on cracks, and come to feel very guilty whenever they do so, whether accidentally or not. In such a society, everybody treats it as a basic, fundamental moral principle that one must not step on cracks, requiring no further explanation or justification. Perhaps no human society could maintain such an absurd taboo over time, but this doesn't affect the point that such moral beliefs are possible, even if only for creatures with very different motivations from our own.

Because, according to expressivists, the sentiments (or others attitudes) that constitute moral judgments can be directed towards any actions, accepting an expressivist metaethical standpoint isn't supposed to limit one's first-order ethical options. That is, in adopting an expressivist metaethical standpoint, one is adopting a certain understanding of what one is doing when one makes a moral judgment-one is directing certain sentiments or attitudes at certain actions. But because those attitudes can be directed at any actions, one hasn't thereby settled any first-order normative questionsone hasn't settled for oneself any questions about which sentiments should be directed at which actions. This is the meaning of Ayer's remark quoted above - on his view, the proper scope of philosophical theorizing was limited to the question of what we're doing when we make ethical judgments, and on his view, accepting the right answer to that question doesn't commit us to making any ethical judgments in particular.

It's natural to think that a similar line should hold in epistemology. That is, an expressivist metaepistemologist will give us an account of what we're doing when we

\footnotetext{
${ }^{3}$ E.g., Blackburn (1998).

${ }^{4}$ E.g., Gibbard (1990).

${ }^{5}$ E.g., Gibbard (2003).
} 
make epistemic judgments about beliefs - classifying them as rational, or justified, or amounting to knowledge. Perhaps we are "expressing, in part, our commitment to a specific set of norms or policies for belief formation." (Chrisman, 2012, p.121) But if just about any norms or policies for belief formation are in principle possible - we might imagine a society where everybody has a policy of always believing that cracks in sidewalks are dangerous, no matter their evidence - then adopting such an understanding of what we're doing in making epistemological judgments won't yet commit us to any such judgments in particular. ${ }^{6}$ If, for instance, we're interested in the first-order epistemological question of whether belief in God is rational given our evidence, adopting metaepistemological expressivism won't help; it will tell us what it would be to have the belief that it is rational (this would amount to having one sort of belief-forming policy), as well as what it would be to have the belief that it's not (this would amount to having a different policy), but those answers won’t help us decide which policy to adopt.

Ultimately, however, I'll argue that this move is too quick; there are important cases where adopting an expressivist understanding of what we're doing when we make epistemological judgments will and should have an impact on which such judgments we make.

\section{Judgment Internalism in Epistemology}

The first example I'll give to problematize the "autonomy of epistemology" — even from an expressivist point of view - concerns the thesis of "judgment internalism." Judgment internalism is a thesis - or family of theses, depending on how broadly it's defined — often associated with expressivist metaethics, but embraced by many non-expressivists as well. Analogs of judgment internalism in metaepistemology, however, have received relatively little discussion. My aim in this section will be to argue that analogs of judgment

\footnotetext{
${ }^{6}$ Given the broadly expressivist meta-epistemological picture defended by Field (2000), this would amount to treating the belief that cracks in sidewalks are dangerous as a priori and indefeasibly justified.
} 


\section{Is Epistemology Autonomous?}

internalism in epistemology have significant consequences for debates in epistemology that would ordinarily be counted as first-order, rather than metaepistemological. In particular, I'll argue that judgment internalism in epistemology fits very naturally with the view that justification for believing that one has justification for believing $\mathrm{p}$ is never misleading - if one has justification for believing that one has justification for believing $\mathrm{p}$, one does in fact have justification for believing.$^{7}$ But since this is a view about which bodies of justification are possible - rather than just a view about what it is to regard a belief as justified - it is naturally classified as a first-order epistemological view, rather than a metaepistemological one.

Metaethical judgment internalists hold that there is some close connection between moral judgment on the one hand, and moral motivation on the other. Perhaps the most commonly discussed version of judgment internalism holds that there is a necessary connection between judging that one morally ought to $\phi$, and being motivated to $\phi{ }^{8}$ A weaker, but related thesis, states that this connection holds not for all agents, but for all rational agents - that is, according to the weaker version of the thesis, rational agents are always motivated to $\phi$ when they judge they morally ought to $\phi .{ }^{9}$ Part of the reason judgment internalism is often a component of expressivist views in metaethics is that it fits naturally with the idea that moral judgments are a distinctive kind of mental state, importantly different from ordinary, non-moral beliefs. For instance, an expressivist who holds that moral judgments just are certain sorts of motivational states has a natural answer to the question of why judgment internalism is true - there is a

\footnotetext{
${ }^{7}$ Throughout this paper I'll slide between talk of what one "epistemically ought" to believe, what one "should" believe, what one would be "justified" in believing, what it would be "rational" to believe, and what one's "evidence" conclusively supports. It's not because I think these are equivalent-each can and have been given fruitfully different readings by various authors. But I don't think they come pre-distinguished - rather, I think there are a number of fruitful distinctions in the neighborhood to be drawn, and neither ordinary language nor epistemological practice has settled on conventions for exactly which distinctions go with which terminology. When the distinctions between the different notions are important, I'll draw attention to it and make explicit which I intend to invoke, but when they are not, I won't.

${ }^{8}$ See Darwall (1983), who coined the term "judgment internalism", for discussion.

${ }^{9}$ This is the version of internalism defended by Smith (1994).
} 


\section{Is Epistemology Autonomous?}

necessary connection between moral judgment and motivation because moral judgment is a species of motivation.

What might an epistemological analog of judgment internalism look like? If we just substitute "epistemic" for "moral", and "believe that p" for " $\phi$ ", we get the following: there is a necessary connection between judging that one epistemically ought to believe that $\mathrm{p}$, and being motivated to believe that $\mathrm{p} .{ }^{10}$ The weaker version of epistemological judgment internalism would say that this connection holds for rational agents-rational agents are always motivated to believe that $\mathrm{p}$ when they judge they epistemically ought to believe that p. The main drawback of this formulation is that talk of what we are motivated to believe is unclear at best and deeply misleading at worst, and so requires some unpacking. I'll try to show how we can understand it in a way that the resulting internalist theses are at least plausible, and fit naturally with broader expressivist approaches to metaepistemology in analogous ways to their metaethical cousins.

The reason talk of motivation for belief is potentially misleading is that it naturally brings to mind the concepts of motivated belief and motivated reasoning, as discussed in the psychological literature on heuristics and biases. ${ }^{11}$ Motivated belief, in this sense, is a species of irrationality - motivated beliefs are, very roughly, beliefs that we hold because it feels good to hold them, rather than because of any rational support they enjoy. If metaepistemological judgment internalism connects this sort of "motivation to believe" to judgments of what we ought to believe, then it is a deeply implausible thesis. I might judge that I epistemically ought to believe something - judge that my

\footnotetext{
${ }^{10}$ This may be a place where the distinction between different epistemic concepts is important. E.g., if epistemic justification is "permissive", in the sense argued by Schoenfield (2014), then while judgment internalism might be plausible for judgments involving the epistemic "ought", an unmodified thesis would not be plausible for judgments about epistemic justification. While I've argued against the sort of permissivism that would make this distinction important — see Greco and Hedden (2016) — for present purposes we needn't settle the uniqueness/permissivism debate. We can simply restrict our discussion to impermissive notions, like the epistemic ought, while remaining agnostic on whether there are any interesting permissive notions.

${ }^{11}$ See, e.g., Kahneman (2011).
} 


\section{Is Epistemology Autonomous?}

evidence conclusively supports it - without having any motivation of this sort to believe it. Suppose my evidence conclusively supports the claim that my son committed a horrible crime. Moreover, suppose I recognize that this is what my evidence supports-I judge that, epistemically speaking, I ought to believe that my son is guilty. Of course it would be devastating for me to accept this, and much more comfortable to somehow ignore or dismiss or explain away the evidence. Motivated reasoning - in the psychologists' sense - would involve doing just that. So I might judge that I ought to believe that my son is guilty, without having any motivation to believe this, in the sense of motivation at play in discussions of motivated belief and motivated reasoning. Moreover, this would not be irrational. So neither the strong internalist thesis, on which there is a necessary connection between epistemological judgment and motivation for belief, nor the weak one on which this connection holds only for rational agents, are plausible when motivation for belief is understood along present lines.

There is another way of interpreting talk of motivation for belief, however, on which the idea of a necessary connection between epistemological judgment and motivation for belief is much more plausible. Think of motivation for belief as simply a species of disposition or inclination to believe, without any special connection to practical interests, or cognitive dissonance reduction, or anything like that. If we return to the example from the previous paragraph, it's natural to think that a realistic version of the case would involve some kind of tension or clash between conflicting dispositions. On the one hand, processes like cognitive dissonance reduction will dispose me to believe that my son is innocent. On the other hand, a rational evaluation of my evidence will dispose me to believe that my son is guilty. Depending on the details of my psychology, one or the other process may win out, or perhaps neither will fully triumph, and I will end up in some conflicted, wavering state, acting in some respects as someone who believes my son is guilty, and in other respects as someone who believes he is innocent. ${ }^{12}$ What's

\footnotetext{
${ }^{12}$ See Schwitzgebel (2001) for discussion of some related cases.
} 


\section{Is Epistemology Autonomous?}

important for present purposes is that, once the case is described as one in which "motivated reasoning" (in the psychological sense) favors one belief, but my epistemological judgment favors another, we think of me as being pulled in two directions - as someone with conflicting internal dispositions. And that's enough to show that we're committed to thinking that epistemological judgment to the effect that one ought to believe that $\mathrm{p}$ is (necessarily? typically?) associated with some sort of disposition to believe that $\mathrm{p}$ - namely, the sort of disposition that conflicts with the dispositions produced by motivated reasoning in cases like the one we've imagined.

To get a better feel for what epistemological judgment internalism might amount to, it may help to think about what it rules out. Debates over judgment internalism in metaethics often center around the character of the amoralist-someone who makes moral judgments, but lacks any motivation to act in accordance with them. ${ }^{13}$ Fiction abounds with apparent amoralists; "I know what morality says I should do, but I don't care about morality!" has a good deal of resonance. Strong internalists will regard amoralists as impossible, and will try to explain away appearances to the contraryperhaps they'll hold that apparent amoralists aren't making genuine moral judgments, but are instead only using moral terms in an "inverted commas" sense. ${ }^{14}$ Weak internalists will allow that amoralists are possible, but regard them as irrational.

Epistemological judgment internalism can be helpfully framed along similar lines. Should we allow for the possibility of the anepistemicist-someone who makes epistemological judgments, but has no tendency to conform her beliefs to them? What might be her rallying cry? Perhaps the following:"I know what the evidence supports, but evidence is a systematically unreliable guide to the truth!" But this won't do; plausibly, to think that some source of information is a systematically poor guide to the truth of

\footnotetext{
${ }^{13}$ See Brink (1989) for a paradigmatic statement of the amoralist-based challenge to judgment internalism.

${ }^{14}$ See Blackburn (1998) for a nuanced treatment of the challenge of amoralism as manifested in the character of Milton's Satan. Blackburn's treatment is ultimately sympathetic to broadly judgment internalist views.
} 


\section{Is Epistemology Autonomous?}

whether $P$ is just to think that it doesn't provide good evidence of whether $P$. The rallying cry of the anepistemicist, then, could only be uttered by somebody who was deeply confused about what "evidence" means. It won't do to point to the possibility of skepticism about the reliability of reason; someone who thinks that ratiocination is a poor guide to the truth is not someone who thinks that evidence is a poor guide to truth, but instead someone who thinks that the fact that a view seems plausible after careful, sustained reflection is at best weak evidence that it is true. ${ }^{15}$

It also won't do to point to the possibility of not caring whether one's beliefs are rational. The following is surely possible; someone might coherently fail to care about having rational beliefs, especially when that conflicts with having comfortable or useful beliefs. ${ }^{16}$ We might imagine someone who, when confronted with compelling psychological research about the various self-serving biases most of us have, along with some evidence about effective strategies for debiasing, reacts as follows. "I'd rather keep my self-serving biases, and continue to form beliefs that feel good to hold, rather than ones that are supported by my evidence. Given the choice between well-adjusted and irrational on the one hand, and depressed and rational on the other, I choose the former! So I won't attempt to employ the de-biasing strategies." Why isn't this character an epistemic analog of the amoralist?

Like many epistemologists, I'm inclined to draw a sharp distinction between evaluation of belief on the one hand, and evaluation of action on the other. ${ }^{17}$ While discussions of amoralism in ethics focus on the question of the coherence of failing to let one's moral judgments guide one's actions, the interesting analog in the epistemological case, I think, would focus on the coherence of failing to let one's epistemic judgments guide one's beliefs. Our imagined character is taking actions - abstaining from debiasing - that, by her

\footnotetext{
${ }^{15}$ See Kornblith (1999) for an exploration of this sort of position. This is, incidentally, how I would interpret fideists, who might initially seem to be examples of anepistemicists.

${ }^{16}$ See, e.g., Rinard $(2015,2017)$, who I interpret as recommending such values. Though Rinard would certainly disagree with the point being made here - she doesn't accept a distinction between epistemic and pragmatic evaluation.

${ }^{17}$ See, e.g., Kelly (2002).
} 
lights, are not causally conducive to having beliefs that are supported by her evidence. But that's not what should strike us as odd or potentially incoherent. Rather, it would be forming beliefs — not merely taking actions that will have predictable causal influence on one's beliefs - that are, by one's own lights, not supported by one's evidence. And while there are debates about whether that is possible, and if so, whether it could be coherent, ${ }^{18}$ no answer to those debates is implied by the manifest possibility of someone whose actions aren't guided by a goal of having well-supported beliefs. If we flesh out our example a bit, suppose that even though our character doesn't care about having beliefs that are well-supported by the evidence, we manage to motivate her-perhaps financially - to listen to enough psychological evidence about self-serving biases that she's ultimately convinced that it's not rational for her to believe she's an above-average driver. The epistemic judgment internalist will claim—plausibly, I think-that if we can succeed in convincing her of that claim about evidence, then we'll have thereby created some motivation on her part to believe that she's not an above-average driver. While I'm surely partisan, it seems to me that, here at least, judgment internalism is more plausible in metaepistemology than metaethics, as the threat from amoralists is more powerful than the threat from anepistemicists.

\subsection{Judgment Internalism and Epistemic Levels}

I've claimed that judgment internalism is relevant to first-order debates, but which ones? The main examples I have in mind concern debates about the relationships between claims at different "epistemic levels". Just as we can ask whether I know that P, we can ask whether I know that I know that $P$, or whether I know that I know that I know that $\mathrm{P}$, and so on all the way up. Likewise with other epistemological concepts, such as probability, evidence, and rationality. We can ask whether $\mathrm{P}$ is probable, but also whether it is probable that $\mathrm{P}$ is probable, or whether it's rational to believe that $\mathrm{P}$, but

\footnotetext{
${ }^{18}$ For arguments to the effect that it's not possible, see Adler (2002). For an argument that it is possible, but constitutively involves a kind of incoherence or "fragmentation", see Greco (2014b).
} 


\section{Is Epistemology Autonomous?}

also whether it's rational to believe that it's rational to believe that $\mathrm{P}$.

Questions about the relationships between claims at different epistemic levels turn out to be relevant to a wide range of epistemological debates. Certain skeptical arguments rely on strong claims about the links between different epistemic levels, and many philosophers have thought that we must reject these level-bridging claims if we are to avoid skepticism. ${ }^{19}$ More recently, debates about how we ought to respond to evidence of our own fallibility - for example, debates about the epistemic significance of disagreement-have often hinged on whether some level-bridging claim is true. ${ }^{20}$

Are there any principles connecting what's true at one level to what's true at another? It used to be thought that there were, but the story of the last forty or so years of epistemology has been, to a significant extent, a story of the rejection of level-bridging principles. ${ }^{21}$ Opposition to level-bringing principles began with reliability theories of knowledge and justification in the 1970s. Roughly, the thought was that a belief's being justified or amounting to knowledge is in large part a matter of it's having been produced by the right sort of process, and questions about whether the processes that produce a subject's first-order beliefs are of the right sort are independent from questions about whether the processes that produce a subject's higher-order beliefs - should she have any - are of the right sort. A subject might have a reliable process for discerning facts about the environment, but lack any self-monitoring processes that would enable her to reliably form true beliefs about what her beliefs are or whether those beliefs are reliably formed. In the other direction, a subject might come to believe that she would be justified in believing that $\mathrm{P}$ by using some reliable process - perhaps relying on the testimony of a trustworthy expert - even though in fact there is no reliable process available to her

\footnotetext{
${ }^{19}$ Jonathan Adler (1981) rejects the principle that knowing entails knowing that one knows on the grounds that it leads to skepticism. For example, Barry Stroud (1984) agrees that the principle leads to skepticism, but defends both the principle and the skeptical conclusion he takes it to entail.

${ }^{20}$ See, e.g., Christensen (2010).

${ }^{21}$ The term "epistemic levels", and the idea that we go wrong in assuming that true claims at one level tend to have implications at others, come from Alston's "Level Confusions in Epistemology" (1980).
} 


\section{Is Epistemology Autonomous?}

that would produce the first order belief that $\mathrm{P} .{ }^{22}$

But more recent years have seen warnings about conflating claims at different levels not tied specifically to reliabilism. For instance, a frequent strategy in a number of recent epistemological debates is to defend some first-level claim-e.g., that a subject knows, or is justified in believing, that $\mathrm{P}$ - by diagnosing apparent contrary considerations as in fact only targeting a higher-level claim - e.g., that a subject knows that she knows, or would be justified in believing that she's justified in believing, that $\mathrm{P}^{23}$ In the remainder of this section, I'll argue that accepting judgment internalism in metaepistemology makes this sort of distinction a bit more difficult to draw.

The reason is that judgment internalism - whether in its strong or weak form - makes it hard to say that a subject $\mathrm{S}$ could appropriately believe that she ought to believe that $\mathrm{P}$, without going on to believe $\mathrm{P}$. So if we accept the second-level claim that $\mathrm{S}$ ought to believe that she ought to believe that $\mathrm{P}$, while rejecting the first-level claim that $\mathrm{S}$ ought to believe that $\mathrm{P}$, we'll have a hard time saying how $\mathrm{S}$ could appropriately respond to her epistemic situation. Suppose $\mathrm{S}$ subject believes that she ought to believe that $\mathrm{P}$, and this belief is justified, rational, supported by the evidence, etc. Given judgment internalism, either she will in fact, or will if she is rational, go on to be motivated to believe that $\mathrm{P}$. Moreover, we should be able to set up the case so that there no conflicting, non-epistemic motivations pushing her away from believing that $\mathrm{P}$ (e.g., the case is not one in which it would be especially painful or difficult to bring herself to accept that P). So suppose she does in fact go on to believe that P. Might this belief nevertheless be inappropriate, unjustified, irrational, or what have you?

Perhaps, but if so, our subject will face a kind of dilemma. We stipulated that she ought to believe that she ought to believe that $\mathrm{P}$, and that she oughtn't believe that $\mathrm{P}$. Given judgment internalism, and the additional stipulation that there are no conflicting,

\footnotetext{
${ }^{22}$ See Greco (2014a) and Das and Salow (2016) for some pushback against these sorts of arguments.

${ }^{23}$ E.g., Williamson (2005) argues that in certain cases where one's epistemic position is intuitively too weak to assert or act on some claim, the problem is not that one doesn't know the claim, but instead that one doesn't know that one knows, or know that one knows that one knows.
} 


\section{Is Epistemology Autonomous?}

non-epistemic considerations inclining her against believing that $\mathrm{P}$, we get the claim that if she believes she ought to believe that $\mathrm{P}$, then she believes that $\mathrm{P}$. So her dilemma is as follows: either she (appropriately) believes that she ought to believe that $\mathrm{P}$, and goes on to (inappropriately) believe that $\mathrm{P}$, or she (inappropriately) fails to believe she ought to believe that $\mathrm{P}^{24}$

I do not claim that this result is fatal for our initial stipulation that she ought to believe that she ought to believe that P, but oughtn't believe that P. While they are controversial, some writers will be happy to accept the existence of epistemic dilemmas. ${ }^{25}$ But it is a surprising, first-order consequence of judgment internalism that, if we accept "mismatched" second-order and first-order epistemic oughts, we must also accept the existence of epistemic dilemmas. In the absence of judgment internalism, we could hold that a subject could appropriately and unconflictedly respond to such "mismatched" oughts by having the higher-order belief that she ought to believe that $\mathrm{P}$, while lacking the first-order belief that $\mathrm{P}$.

Before moving on, I'd like to point to one way in which this conclusion is a bit stronger than some related ones in the literature. It's been noted-for example, by Littlejohn (2012) — that, if we have a "factive" conception of epistemic oughts, then this sort of downward level-bridging principle is unsurprising, and in fact trivial - e.g., if one only ought to believe what one knows, and ipso facto only ought to believe what is true, then we can very quickly get the result that if one ought to believe that one ought to believe that $\mathrm{P}$, then one ought to believe that P. It's a consequence of the fact that if it's true that it's true that $\mathrm{P}$, then it's true that $\mathrm{P}$. But it seems to me that something like the above strategy may generalize to epistemic notions that all parties will agree are

\footnotetext{
${ }^{24}$ See Way and Whiting (forthcoming) citation for a very similar argument in favor of a similar principle concerning action. They don't appeal to judgment internalism, but instead to the idea that it is correct to reason from the claim that one ought to $\phi$ to a decision to $\phi$. That is, rather than saying that if you judge that ought to $\phi$, then you will go on to $\phi$ (given judgment internalism), they say that if you judge that you ought to $\phi$, then it would be correct reasoning to go on to decide to $\phi$. But the overall structure of the argument, and the aim of putting pressure on the "level-splitting" position that the belief that one ought to $\phi$ might be appropriate even while a decision to $\phi$ would not be, are similar.

${ }^{25}$ See Ross (2010) and Moss (2014) for defenses of the existence of certain sorts of epistemic dilemmas.
} 
non-factive. For instance, if we accept judgment internalism, then it's plausible that just as judging outright that one ought to believe that $\mathrm{P}$ will motivate one to believe that $\mathrm{P}$, being confident that one ought to be confident that $\mathrm{P}$ will have some kind of first-order effect-perhaps inclining one to be confident that $\mathrm{P} .{ }^{26}$ But since appropriate confidence is not factive, the quick argument from earlier in this paragraph won't do anything to rule out the possibility that, e.g., a subject might be appropriately confident that she is appropriately confident that $\mathrm{P}$, when in fact her confidence in $\mathrm{P}$ is misplaced-she should instead be very confident that $\mathrm{P}$ is false. Given the argument I've offered, that position also threatens to lead to an epistemic dilemma, at least if an attractive version of judgment internalism holds - as it seems plausible to me that it should - that being confident that one should be confident that $\mathrm{P}$ has non-trivial implications concerning one's motivation to be confident that $\mathrm{P}$.

In the next section, I'll consider some epistemological consequences of a more thoroughgoing epistemic expressivism — one that starts with the sort of judgment internalism I've been discussing so far, and runs with it.

\section{From Judgment Internalism to Epistemic Expressivism}

One route to epistemic expressivism is to take the idea that there is some kind of intimate connection between epistemological judgment and motivation for belief - epistemological judgment internalism - and to hold that this connection gives epistemological judgment its purpose. That is, the function of epistemological judgment is entirely explained by its connection to motivation for (non-epistemological) belief. For instance, by using language to express epistemological judgments, we can make explicit what we're motivated to believe, (Brandom, 1994) which may make it easier to form and express plans

\footnotetext{
${ }^{26}$ This is non-trivial; typically judgment internalism is phrased as a thesis about the consequences of judging outright that some ought claim is true. It is non-obvious how, if at all, it should be extended to get a thesis about the consequences of being confident that some ought claim is true.
} 
concerning what to believe in hypothetical situations, and to deliberate and coordinate with others concerning which such plans to adopt (Gibbard, 2003). ${ }^{27}$ Epistemological debates, then, can be understood as debates about whether to adopt various competing plans concerning what to believe under specified circumstances. For instance, a debate over whether certain sorts of radio signals would be conclusive evidence of intelligent life on other planets can be understood as a debate over whether or not to adopt the plan to believe in intelligent extraterrestrial life upon discovering such radio signals. Or to take an example closer to recent epistemological practice, debates about the epistemic significance of disagreement can be understood as debates about what plans we should adopt concerning what to believe when confronted with disagreement. ${ }^{28}$ Debates about self-locating belief can be understood as debates over, inter alia, what plans to adopt concerning what to believe upon finding yourself in a predicament like that of Elga's Sleeping Beauty (2000). Developing and defending a version of epistemic expressivism based on the idea of judgment internalism as a starting point is well beyond the scope of this paper. But I think it's not too much to hope that we can draw out some consequences of the thought that the connection to motivation for belief isn't merely an interesting feature of epistemological judgment, but is instead it's raison d'etre.

One consequence of this metaepistemological view is that first-order epistemological debates that lack any connection to motivation for belief are pointless. That is, if some putative first-order epistemological debate lacks any connections to our motivations for belief, then so much the worse for the debate; it is somehow disordered. ${ }^{29}$ So epistemic expressivism might affect how we conduct first-order epistemological debates not by

\footnotetext{
${ }^{27}$ Here having a plan must amount to or at least involve being motivated to comply with it.

${ }^{28}$ One way of reading this debate is that "steadfasters" like, perhaps, Van Inwagen (1996), think we should plan to stick to our guns in cases of disagreement, concilliationists like Christensen (2007) and Elga (2007) think we should adopt some version of a "split the difference" plan, and still other writers deny that there is any general plan we should adopt about how to respond to peer disagreement Kelly (2010), Enoch (2010).

${ }^{29}$ What does this "disorder" amount to? Here are some options, between which I hope I needn't pick. The debates might suffer from presupposition failure, and/or they might concern questions about which there are "truth-value gaps", and/or they might concern questions whose answers are necessarily unknowable.
} 
inclining us to come down on one or the other side of them, but instead by convincing us to abandon them as misguided. And in cases where we're not sure whether some first-order debate is in good standing, adopting this metaepistemological stance might help us decide that question - could settling the debate one way or another have some impact on what we're motivated to believe (about non-epistemological matters)? If so, then it is not misguided. If not, then it is. ${ }^{30}$

In the next subsection I'll take an example of a first-order epistemological debate that some philosophers have suspected may be somehow disordered, or merely verbal, or non-substantive, and I'll show how adopting the sort of expressivism I've been discussing might help us evaluate that suspicion.

\subsection{Epistemic Expressivism and the Internalism/Externalism Debate}

In "Epistemic Desiderata" (1993), William Alston argued that many debates about what's required for a belief to be justified are not substantive. He later developed this position in his book Beyond Justification (2005). Very roughly, Alston's position is that while there are various properties beliefs might have such that it is uncontroversially desirable from an epistemic point of view that beliefs should have these properties, there are no substantive debates to be had about which combinations of these properties beliefs must have to merit the label "justified."

It will help to spell out his position in some more detail to get an idea of which sorts of epistemological debates he thinks are merely verbal. Consider the following list of properties that beliefs can have, each of which has been thought by some philosophers to have some important connection to epistemic justification: ${ }^{31}$

Reliability: A belief might be such that it was produced by an objectively reliable

\footnotetext{
${ }^{30}$ This heuristic is similar to the "transmission of substantiveness" principle I defend in Greco (2015).

${ }^{31}$ This list is based on the lists in Alston's work, specifically (1993, pp. 528-30) and (2005, pp. 12-15). Doubtless many more properties could be added.
} 


\section{Is Epistemology Autonomous?}

process - a process with a high objective chance of producing true beliefs. ${ }^{32}$

Coherence: A belief might be such that it is part of a coherent web of beliefs, in which the various elements of the web bear certain explanatory and inferential connections to one another. ${ }^{33}$

Perceptual Phenomenal Grounding: A belief might be based on perceptual phenomenology. For instance, I might believe that some table is red because it looks red to me. ${ }^{34}$

Ratifiability: A belief might be such that its holder would continue to hold it even after sustained reflection on the question of whether it is true. ${ }^{35}$

Virtuous Basis: A belief might be held as a result of its holder exercising some intellectual virtue. ${ }^{36}$

Defensibility: A belief might be such that its holder is in a position to give a compelling argument in defense of it. ${ }^{37}$

Concerning a similar list of conditions beliefs might satisfy, Alston (1993, p. 531) holds that "for each condition, no one denies that it is desirable to satisfy it, and desirable from an epistemic point of view, desirable vis-á-vis the basic aims of the cognitive

\footnotetext{
${ }^{32}$ See Goldman (1979) for a view identifying justification with reliability in something like the above sense.

${ }^{33}$ Coherentists such as Quine and Ullian (1978) and early time-slices of Laurence BonJour (e.g., the Bonjour of The Structure of Empirical Knowledge) hold that coherence in something like the above sense is required for justification.

${ }^{34}$ See Pollock (1974) and Pryor (2000) for views on which perceptual phenomenology plays an important role in justifying beliefs.

${ }^{35}$ See Foley (2001) for a view on which something like ratifiability in the above sense is necessary and sufficient for justification.

${ }^{36}$ Virtue epistemologists tend to understand knowledge and justification in terms of epistemic virtues. See DePaul and Zagzebski (2003) for a representative collection.

${ }^{37}$ See Leite (2004) for a defense. BonJour (1985), while less explicit,, does seem to think that for a belief to be justified, its holder must have at least some tacit grip on an argument that would vindicate it. See also, Williamson (2007) and Kelly (2010) on the "dialectical conception of evidence", which is closely related to the view just mentioned, and which they both argue against.
} 


\section{Is Epistemology Autonomous?}

enterprise." 38 Alston goes on to argue that while we can ask, for any particular epistemic desideratum, whether a belief exhibits it, there isn't a substantive debate to be had about which of these desiderata make for justification:

If we take the range of parties to the disputes we have been considering...there does not seem to be enough commonality in their pre-theoretical understanding of the nature of epistemic justification to warrant us in supposing that there is some uniquely identifiable item about which they hold different views. It seems, rather, that they are highlighting, emphasizing, "pushing" different concepts, all called 'justification'. It seems, to switch to the perspective of this paper, that they are selecting different epistemic desiderata, or packages thereof, as deserving of the honorific 'justification'. (1993, p. 534)

The implications of this position are most cleanly brought out when we consider particular cases in which beliefs exhibit some, but not other epistemic desiderata. Consider the following two cases:

Clairvoyant Claire: Claire is a reliable clairvoyant, though she does not believe herself to be clairvoyant; she's agnostic about the existence of clairvoyance. Claire's clairvoyance causes her to believe that the president is in New York. While her belief was formed by a reliable process, she doesn't have any evidence that it is true, nor does she have other beliefs which support the belief that the president is in New York. ${ }^{39}$

Hallucinating Hal: It looks to Hal as if there is an apple on the table in front of him, and this leads him to believe that there is an apple on the table in front of him. He

\footnotetext{
${ }^{38}$ Exactly what the idea of a belief's being "desirable from an epistemic point of view" amounts to is a tricky matter, and it's not clear how much adverting to the "basic aims of the cognitive enterprise" helps. While Alston thinks the aim of storing true information is basic to the cognitive enterprise, he notes that no parties to debates about justification have been tempted to simply identify justified beliefs with true ones. I'll avoid these thorny issues here.

${ }^{39}$ This case is inspired by the various cases of reliable clairvoyance discussed by BonJour (1985).
} 


\section{Is Epistemology Autonomous?}

takes his vision to be operating normally, and he believes that visual perception is a reliable process. In fact, Hal's belief is not based on visual perception, but was instead caused by drug-induced hallucination — not a reliable belief-forming process. He has no evidence that this is the case.

Claire's belief is reliablly formed, but it lacks most of the other desiderata mentioned above. $^{40}$ Hal's belief is not reliably formed, but it does seem to have many of the rest of the desiderata on the above list. ${ }^{41}$

Epistemologists in the internalist tradition - very roughly, philosophers who hold that whatever justifies our beliefs must be in some sense accessible to our subjective perspective - tend to hold that beliefs like Claire's are unjustified, while beliefs like Hal's are justified. ${ }^{42}$ Epistemologists in the externalist tradition-very roughly, philosophers who emphasize the epistemological significance of causal/nomological connections between subjects and the external world - tend to give the opposite set of verdicts. ${ }^{43,44}$ According to Alston, however, in disagreeing over whether Claire's and Hal's beliefs are justified, internalists and externalists are not really having a substantive debate. Claire's and Hal's beliefs each have different things going for them; internalists have correctly identified some desirable features that Claire's belief lacks which Hal's belief has, while externalists have equally correctly identified some other desirable features that Hal's belief lacks and which Claire's belief has. Once we recognize this, according to Alston, we should give up the idea that there's some further debate to be had between internalists

\footnotetext{
${ }^{40}$ The one tricky case is the "virtuous basis" case, since so much depends on how epistemic virtues are understood.

${ }^{41}$ Though for the reasons in the prior note, we might hold that Hal fails to manifest an epistemic virtue in holding his belief.

${ }^{42}$ See BonJour (1985), Conee and Feldman (2004) for two paradigm statements of epistemological internalism.

${ }^{43}$ See Armstrong (1973) and Goldman (1979) for two paradigm statements of epistemological externalism.

${ }^{44} \mathrm{Or}$ at least, these are the verdicts that follow from the simplest, easiest-to-state versions of the views. Many externalists, however, are concerned to avoid the result that Claire's belief is justified. Nevertheless, I think it's fair to say that avoiding this result requires more work for the externalist than the internalist.
} 


\section{Is Epistemology Autonomous?}

and externalists.

Fully stating and evaluating Alston's case that debates like the one above-he focuses on debates between internalists and externalists in much of his discussion - are not substantive is beyond the scope of this paper. Instead, I'll try to show how adopting the metaepistemological perspective I've been discussing may provide some support for his conclusion, albeit not for the reasons he offers.

Internalists and externalists disagree over whether the subjects of examples like these have justified beliefs - internalists think that Claire is unjustified and Hal is justified, while externalists hold the opposite set of views. But could this difference ever manifest itself in different motivations to form non-epistemological beliefs? It's far from obvious, as the following discussion will elucidate.

Suppose our internalist finds herself in a situation like Claire's. While the internalist will initially believe that the president is in New York, if she reflects on her epistemic situation and deliberates with the aim of holding a justified belief on the matter of the president's whereabouts, she'll likely be motivated to abandon this belief; by her lights, it will seem to be unjustified. However, the same is true for the externalist. Suppose our externalist finds himself in a situation like Claire's - he believes that the president is in New York, and in fact this belief was caused by a reliable process, but he has no reason to suspect this. If the externalist reflects on the epistemic status of his belief he'll be motivated to abandon it; by his lights, the belief is no more likely to be right than a guess, since he doesn't take it to have been caused by a reliable process. The upshot is that the internalist and the externalist would find themselves motivated to adopt the same attitudes concerning the president's whereabouts - each would abandon the belief that the president is in New York-were they to find themselves in a situation like Claire's.

What if they found themselves in a situation like Hal's? In such a case, the internalist would maintain her belief that there is an apple on the table - by her lights, this belief 


\section{Is Epistemology Autonomous?}

would be justified, since supported by excellent perceptual evidence. The externalist would also take his belief to be justified; he would take it to have been caused by visual perception, a reliable process. As in the earlier case, both the internalist and the externalist would, if they reflected on their epistemic situation with the aim of retaining only justified beliefs, come to the same conclusions.

We can try to say something a bit more general here. For a subject to be able to use her commitments on the internalism/externalism debate to reason her way to distinctive conclusions in particular cases, she would need to be able to take herself to be in a situation in which internalists and externalists would give different verdicts concerning what she ought to believe. That is, she would need to be able to think something like the following to herself: "If externalism is right, I should believe that $P$, but if internalism is right, I should not believe that $P . "$ But the nature of the cases in which internalism and externalism give different verdicts precludes the subjects of those cases from coherently having such thoughts. In order to have such thoughts, subjects would need to believe Moore-paradoxical claims like the following:

My belief that $P$ was caused by a reliable process, but I don't know/believe/have justification to believe that my belief that $P$ was caused by a reliable process.

Only with beliefs like these could subjects straightforwardly take themselves to be in situations in which externalism makes one recommendation, while internalism makes another. But if we never find ourselves in such cases - plausibly, normal agents never believe such Moore-paradoxical claims - then we'll never be able to regard ourselves as inhabiting situations in which externalism and internalism make different recommendations for us. So we'll never be able to use a commitment to internalism (or externalism) to reason our way to accepting one or the other such recommendation. ${ }^{45}$

\footnotetext{
${ }^{45}$ Isn't this too quick? Perhaps a subject couldn't be certain that externalism and internalism make different recommendations - that would require believing a Moore-paradoxical proposition — but couldn't she suspect that she's in such a situation, and mightn't that make a difference to her motivations to believe? After all, there's no incoherence in suspecting that some Moore-paradoxical proposition
} 
Might we get a clearer distinction when we focus on third-person evaluations, rather than first-person ones? It's true that if I as a well-informed third-party know all the relevant facts, depending on whether I'm an internalist or an externalist, I'll give different verdicts concerning whether Claire's and Hal's beliefs are justified. Might this manifest itself in differential dispositions to rely on them, and/or treat them as reliable informants? ${ }^{46}$ It's doubtful - any plausible version of internalism will allow that when I know that somebody's belief that $\mathrm{P}$ is produced by a highly reliable clairvoyant faculty, I should be happy to take their word that P, even if I don't think their belief is justified. And any plausible version of externalism will allow that the fact that somebody trusted their eyes in a one-off case of hallucination — suppose they were drugged - shouldn't lead me to rely on them less in the future. So I'm skeptical that these differing third-party epistemic evaluations could manifest themselves in differential dispositions to rely on somebody's word. ${ }^{47}$

What does this show? At best, it shows that, from the metaepistemological perspective I've been exploring, it's not obvious that the internalism/externalism debate has a point; it's hard to see how coming down one way or the other on the debate could make a difference to our motivations for belief. While this may seem like the beginnings of a vindication of Alston, I suspect that's actually a bit too quick. Granting for the sake of argument that coming down one way or the other on internalism vs externalism won't make a difference to our motivations for belief, the foregoing suggests some closely related reasons for preferring internalism. If we adopt an internalist constriant on justification, then further debates we have about what it takes for beliefs to be justified will is true. While the dialectic becomes more complicated once we make this move-we'll need to say something about what our subject will be motivated to believe when her preferred theory, together with her background beliefs, only delivers probabilities concerning what she ought to believe, rather than outright entailments - I doubt it will save the debate. Whatever the externalist is motivated to believe when she suspects that she's in a Moore-paradoxical case, I conjecture that we'll be able to find a version of internalism which, if adopted, would produce the same motivations for belief. For some support for this claim, see Wedgwood (2002) and Schoenfield (2015).

${ }^{46}$ See, e.g., Dogramaci (2012), drawing on Craig (1990), who argues that the central role of epistemic evaluations is to help us identify reliable informants.

${ }^{47} \mathrm{I}$ discuss some closely related issues in $\S 3.3$ of Greco (2015). 


\section{Is Epistemology Autonomous?}

be guaranteed to have an impact on our motivations for belief. That is, our internalist constraint will tell us that there can only be a distinction between what we are justified in believing in circumstances $\mathrm{C}$ and what we are justified in believing in circumstances $\mathrm{C}^{*}$ if we are capable of distinguishing those circumstances, in a way that would lead to our having different motivations for belief in the different circumstances. ${ }^{48}$ So if we adopt a view that says we're justified in believing $\mathrm{P}$ in $\mathrm{C}$, but not in $\mathrm{C}^{*}$, then we'll be motivated to believe $\mathrm{P}$ when we find ourselves in $\mathrm{C}$, but not when we find ourselves in $\mathrm{C}^{*}$. By contrast, if we have no such constraint - if we are externalists - we may all agree on what to believe in $\mathrm{C}$, while disagreeing about what to believe in some indistinguishable $\mathrm{C}^{*}$. And it's hard to see how settling this debate could make a difference to our motivations for belief. For instance, suppose we all agree that when you see smoke and have no suspicions otherwise, you should believe there is fire. But we disagree about what you should believe when you think you see smoke (and have no suspicions otherwise), but in fact you are hallucinating. One of us thinks you should still believe there is fire, while the other thinks you should remain agnostic about the presence of fire. Settling this debate couldn't make a difference to what you're motivated to believe (since the differences between the positions only show up under conditions that you could never take yourself to be in). So even if the internalism/externalism debate itself lacks connections to motivations for belief, adopting internalism may guard us against getting into further debates about justification that lack connections to motivations for belief.

I don't pretend to have shown exactly what the ultimate consequences of adopting an expressivist metaepistemology are for the internalism/externalism debate; I leave open that there may be strategies I haven't considered that the expressivist might pursue that would leave the debate looking more robustly substantive than I've allowed, and which

\footnotetext{
${ }^{48}$ See Schafer (2014) for a very similar argument that internalism fits much more naturally than externalism with a plan-based epistemic expressivism. Of course, arguments like mine and Schafer's at some point have to reckon with powerful arguments from Williamson (2000) to the effect that no properties - justification, rationality, or anything else - are subject to the sort of internalist constraint we've been discussing. While it's beyond the scope of the present paper to address such issues, I do discuss them in other work. See Greco (2014a), Greco (2016), and Greco (2017).
} 
Is Epistemology Autonomous?

could ultimately lead to favoring externalism. I do hope, however, that I've shown that the debate looks quite different once we adopt this metaepistemological perspective.

\section{Conclusions}

At the beginning of this paper I acknowledged that the thesis of the "autonomy of ethics" is often associated with expressivist metaethics, and I then went on to give two examples meant to put pressure on the idea that an analogous autonomy thesis should be attractive to expressivist metaepistemologists. This might seem puzzling, as the general trend in recent work is in the direction of emphasizing the continuity of metaethics and metaepistemology — it's all really just metanormativity — and to treat questions as arising in parallel in the two domains. ${ }^{49}$ As I'm sympathetic to that trend, in this final section I'll briefly sketch how the sorts of considerations I've adduced here could be used, mutatis mutandis to put pressure on the autonomy of ethics.

I've argued that judgment internalism has significant consequences for debates about the relationship between judgments at different epistemic levels, which would typically be classified as a debate at the level of first-order epistemology, rather than metaepistemology. Is there some analogous debate in first-order ethics that judgment internalism might have similar consequences for? There is, though it's not one that has received as much attention as the parallel epistemological debate. Just as we can ask questions about which actions we are morally obligated to perform, we can ask questions about which actions we are morally obligated to believe we are morally obligated to perform. For instance, could it ever be that while I morally ought to lie, I morally ought to believe that I morally oughtn't lie? While we might be tempted to think that all obligations for belief must be epistemic, rather than moral - and so that asking questions about

\footnotetext{
${ }^{49}$ This view tends to be common ground among writers of a wide variety of metaethical persuasions. For some examples of recent treatments of metaepistemological issues in parallel to metaethical ones, see Cuneo (2007), Chrisman (2007), and Street (2009a, 2010).
} 


\section{Is Epistemology Autonomous?}

what I am morally obligated to believe would be a mistake - there are good reasons for denying such a thesis, ${ }^{50}$ and once we do there's no obvious obstacle to ethicists asking questions about the relationships between "moral levels" that are exactly analogous to questions about epistemic levels that have exercised so many epistemologists. I suspect that if my arguments from $\S 2$ are correct, then an analogous conclusion to the one I draw there will hold in ethics: adopting judgment internalism creates pressure to accept strong connections between what one is morally obligated to do, and what one is morally obligated to believe one is morally obligated to do. Moreover, while typically not put in quite these terms, there is extant work in ethics that is naturally interpreted as getting at just these questions. For instance, certain debates over whether moral ignorance is exculpatory - whether ignorance of moral facts is an excuse for wrongful action - concern the question of whether we are morally obligated not to have false beliefs about morality. ${ }^{51}$ If judgment internalism has significant consequences for that debate, then that's a strike against the autonomy of ethics.

What about the second example, concerning internalism and externalism in epistemology? Here there are also analogous debates in ethics, though they go under different labels. There has been a great deal of work on the extent to which a subject's moral obligations depend on facts accessible to her. Some writers hold that a "subjective" conception of obligation - on which facts about what a subject is obligated to do depend entirely on facts accessible to that subject-is the primary or philosophically most significant one, and try to derive apparent facts about "objective" oughts in terms of their preferred subjective notion. ${ }^{52}$ Others treat more objective conceptions - on which

\footnotetext{
${ }^{50}$ For instance, suppose we accept, with Gibbard (1990, p. 42), that "what a person does is morally wrong if and only if it is rational for him to feel guilty for having done it, and for others to feel angry at him for having done it." Given such a view, we can get an abstract characterization of what it would take for a belief to be morally wrong - just replace "does" with "believes" and "done it" with "believed it." And then it's a highly substantive claim, requiring serious argument, that it's never rational to feel guilty for a belief, or to feel angry with others for their beliefs. I invite you, reader, to consider the beliefs you feel most strongly about, and then ask whether it's obvious that it could never be rational to be angry with someone for holding diametrically opposed beliefs.

${ }^{51}$ See, e.g., Rosen (2002, 2004), Harman (2011).

${ }^{52}$ For example, Jackson (1991), Kiesewetter (2011), Zimmerman (2014).
} 


\section{Is Epistemology Autonomous?}

there is no restriction whatsoever on what sorts of facts are relevant to determining a subject's obligations - as primary, and explain away intuitions about putatively subjective conceptions of obligation as really concerning blame, or excusability. ${ }^{53}$ Still others reject the distinction between subjective and objective conceptions of obligation, holding instead that all obligation claims are somehow tacitly relative to a body of information, which might be fleshed out in various ways. ${ }^{54}$ For instance, when obligation claims are made relative to the body of information accessible to some subject, we get a subjective obligation; when they are made relative to all information, we get an objective obligation. But there are important intermediate cases that the traditional distinction doesn't capture.

While making a case for this claim is beyond the scope of this paper, my suspicion is that adopting an expressivist metaethics has similar methodological upshots in this debate as it does in the debate between epistemic internalists and epistemic externalists. That is to say, it would provide a clearer picture of just how the competing positions must differ if the debate between them is to be a well-ordered one, worth having. In particular, if partisans of subjective-first or objective-first conceptions of obligation are ultimately motivated to perform the same actions in the same circumstances, then the debate is in trouble. Obviously I can't make a case for that here, and for what it's worth I'm agnostic about whether such a case could be made. But whether or not it could, we'd have an example where a metaethical position - epistemic expressivism — provided some guidance in how to conduct a debate that would ordinarily be classified as one of normative ethics, rather than metaethics. Another strike against autonomy.

Ultimately, while the expressivist should allow that autonomy theses get certain cases right - expressivism won't tell you what to think about the morality of abortion, or the evidence for extraterrestrial life - they are overgeneralizations. Adopting expressivist metanormative views can legitimately influence how we conduct first-order normative

\footnotetext{
${ }^{53}$ See Thomson (1986), Graham (2010).

${ }^{54}$ See Kolodny and MacFarlane (2010).
} 
debates, whether in epistemology or ethics.

\section{Bibliography}

Adler, J., 2002. Belief's Own Ethics, volume 112. MIT Press.

Adler, Jonathan. 1981. "Skepticism and Universalizability." The Journal of Philosophy $78: 143-156$.

Alston, William, 2005. Beyond "Justification": Dimensions of Epistemic Evaluation. Cornell University Press.

Alston, William P. 1980. "Level Confusions in Epistemology." Midwest Studies in Philosophy 5(1):135-150.

—. 1993. "Epistemic Desiderata." Philosophy and Phenomenological Research $53: 527-551$.

Armstrong, D. M., 1973. Belief, Truth and Knowledge,. London,Cambridge University Press.

Ayer, Alfred Jules, 1971. Language, Truth, and Logic. Pelican.

Blackburn, Simon, 1998. Ruling Passions. Oxford University Press.

BonJour, Laurence, 1985. The Structure of Empirical Knowledge. Cambridge, MA: Harvard University Press.

Brandom, Robert, 1994. Making It Explicit: Reasoning, Representing, and Discursive Commitment. Cambridge, Ma.: Harvard University Press.

Brink, David, 1989. Moral Realism and the Foundations of Ethics. Cambridge University Press. 
Is Epistemology Autonomous?

Chrisman, Matthew. 2007. "From Epistemic Contextualism to Epistemic Expressivism." Philosophical Studies 135:225-254.

2012. "Epistemic Expressivism." Philosophy Compass 7:118-126.

Christensen, David. 2007. "Epistemology of Disagreement: The Good News." Philosophical Review 116:187-217.

. 2010. "Higher-Order Evidence." Philosophy and Phenomenological Research $81: 185-215$.

Conee, Earl, and Richard Feldman, 2004. Evidentialism. Oxford: Oxford University Press.

Craig, Edward, 1990. Knowledge and the State of Nature: An Essay in Conceptual Synthesis. Oxford: Clarendon Press.

Cuneo, Terence, 2007. The Normative Web: An Argument for Moral Realism. Oxford University Press.

Darwall, S., 1983. Impartial Reason. Cornell University Press.

Das, Nilanjan, and Bernhard Salow. 2016. "Transparency and the KK Principle." Nô̂s

DePaul, Michael R., and Linda Trinkaus Zagzebski, 2003. Intellectual Virtue: Perspectives From Ethics and Epistemology. Oxford University Press.

Dogramaci, Sinan. 2012. "Reverse Engineering Epistemic Evaluations." Philosophy and Phenomenological Research 84:513-530.

Elga, Adam. 2000. "Self-Locating Belief and the Sleeping Beauty Problem." Analysis 60:143-147. 
- 2007. "Reflection and Disagreement." Nous 41:478-502.

Enoch, D. 2010. "Not Just a Truthometer: Taking Oneself Seriously in Cases of Peer Disagreement." Mind 119:953-997.

Field, Hartry, 2000. "A Priority as an Evaluative Notion." In Boghossian, Paul A., and Christopher Peacocke, editors, "New Essays on the A Priori," Oxford: Oxford University Press.

Foley, Richard, 2001. Intellectual Trust in Oneself and Others. Cambridge University Press.

Gibbard, Allan, 1990. Wise Choices, Apt Feelings. Cambridge Massachussetts: Harvard University Press.

—, 2003. Thinking How to Live. Cambridge, Ma.: Harvard University Press.

Goldman, Alvin, 1979. "What is Justified Belief?" In Pappas, George S., editor, "Justification and Knowledge," Reidel.

Graham, Peter A. 2010. "In Defense of Objectivism About Moral Obligation." Ethics 121:88-115.

Greco, Daniel. 2014a. "Could KK Be OK?” Journal of Philosophy 111:169-197.

—. 2014b. "A Puzzle About Epistemic Akrasia." Philosophical Studies 167:201-219.

—. 2015. "Verbal Debates in Epistemology." American Philosophical Quarterly $51: 41-55$.

—. 2016. "Safety, Iteration, Explanation." Philosophical Issues .

— , 2017. "Contextualism about Foundations." In Ichikawa, Jonathan Jenkins, editor, "Routledge Handbook of Epistemic Contextualism," Routledge. 


\section{Is Epistemology Autonomous?}

Greco, Daniel, and Brian Hedden. 2016. "Uniqueness and Metaepistemoloy." Journal of Philosophy 113.

Harman, Elizabeth. 2011. "Does Moral Ignorance Exculpate?" Ratio 24:443-468.

JACKSON, FRANK. 1991. "Book Reviews." Mind C:403-406.

Kahneman, Daniel, 2011. Thinking, Fast and Slow. Farrar, Straus and Giroux.

Kelly, Thomas. 2002. "The Rationality of Belief and Other Propositional Attitudes." Philosophical Studies 110:163-96.

— 2010. "Peer Disagreement and Higher Order Evidence." In "Disagreement," Oxford University Press.

Kiesewetter, Benjamin. 2011. "'Ought' and the Perspective of the Agent." Journal of Ethics and Social Philosophy 5:1-24.

Kolodny, Niko, and John MacFarlane. 2010. "Ifs and Oughts." Journal of Philosophy $107: 115-143$.

Kornblith, Hilary. 1999. "Distrusting Reason." Midwest Studies in Philosophy 23:181196.

Korsgaard, Christine M., 2000. The Sources of Normativity. Cambridge: Cambridge University Press.

Leite, Adam. 2004. "On Justifying and Being Justified." Philosophical Issues 14:219253.

Littlejohn, Clayton, 2012. Justification and the Truth Connection. Cambridge University Press.

McPherson, Tristram. 2011. "Against Quietist Normative Realism." Philosophical Studies 154:223-240. 
Is Epistemology Autonomous?

Moss, Sarah. 2014. "Credal Dilemmas." Noûs 48:665-683.

Pollock, John, 1974. Knowledge and Justification. Princeton, NJ: Princeton University Press.

Pryor, James. 2000. "The Skeptic and the Dogmatist." Nô̂s 34:517-549.

Quine, W.V.O., and J.S. Ullian, 1978. The Web of Belief. McGraw-Hill.

Rinard, Susanna. 2015. "Against the New Evidentialists." Philosophical Issues 25:208223.

2017. "No Exception for Belief." Philosophy and Phenomenological Research 94:121-143.

Rosen, Gideon. 2002. "Culpability and Ignorance." Proceedings of the Aristotelian Society 103:61-84.

—. 2004. "Skepticism About Moral Reasponsibility." Philosophical Perspectives 18(1):295-313.

Ross, Jacob. 2010. "Sleeping Beauty, Countable Additivity, and Rational Dilemmas." Philosophical Review 119:411-447.

Schafer, Karl. 2014. "Doxastic Planning and Epistemic Internalism.” Synthese 191:25712591.

Schoenfield, Miriam. 2014. "Permission to Believe: Why Permissivism Is True and What It Tells Us About Irrelevant Influences on Belief." Noûs 48:193-218.

—. 2015. "Internalism Without Luminosity." Philosophical Issues 25:252-272.

Schroeder, Mark, Forthcoming. "Normative Ethics and Metaethics." In Plunkett, David, and Tristram McPherson, editors, "Routledge Handbook of Metaethics," Routledge. 
Is Epistemology Autonomous?

Schwitzgebel, Eric. 2001. "In-Between Believing." Philosophical Quarterly 51:76-82.

Smith, Michael, 1994. The Moral Problem. Blackwell.

Street, Sharon. 2009a. "Evolution and the Normativity of Epistemic Reasons." Canadian Journal of Philosophy 39:213-248.

—. 2009b. "In Defense of Future Tuesday Indifference: Ideally Coherent Eccentrics and the Contingency of What Matters." Philosophical Issues 19:273-298.

—. 2010. "What is Constructivism in Ethics and Metaethics?" Philosophy Compass $5: 363-384$.

Stroud, Barry, 1984. The Significance of Philosophical Skepticism. Oxford: Oxford University Press.

Thomson, Judith Jarvis, 1986. "Imposing Risks." In "Rights, Restitution, and Risk: Essays in Moral Theory," Harvard University Press.

Van Inwagen, Peter, 1996. "It is Wrong, Everywhere, Always, and for Anyone, to Believe Anything upon Insufficient Evidence." In Jordon, Jeff, and Daniel Howard-Snyder, editors, "Faith, Freedom, and Rationality," pages 137-154. Rowman and Littlefield.

Way, Jonathan, and Daniel Whiting. forthcoming. "If You Justifiably Believe That You Ought to $\Phi$, You Ought to $\Phi . ”$ Philosophical Studies pages 1-23.

Wedgwood, Palph. 2002. "Internalism Explained." Philosophy and Phenomenological Research 65:349-369.

Williamson, Timothy, 2000. Knowledge and its Limits. Oxford University Press.

—. 2005. "Contextualism, Subject-Sensitive Invariantism and Knowledge of Knowledge." Philosophical Quarterly 55:213-235. 
Is Epistemology Autonomous?

— 2007. The Philosophy of Philosophy. Oxford: Blackwell.

Zimmerman, Michael, 2014. Ignorance and Moral Obligation. Oxford University Press. 